\title{
Lymphoepithelial Cysts of the Pancreas: a Report of 12 Cases and a Review of the Literature
}

\author{
N. Volkan Adsay, M.D., Farnaz Hasteh, M.D., Jeanette D. Cheng, M.D., Pablo A. Bejarano, M.D., \\ Gregory Y. Lauwers, M.D., Kenneth P. Batts, M.D., Günter Klöppel, M.D., David S. Klimstra, M.D. \\ Departments of Pathology, Karmanos Cancer Institute (NVA, FH) and Wayne State University School of \\ Medicine, Detroit, Michigan; Department of Pathology, Providence Hospital (JDC), Detroit, Michigan; \\ Department of Pathology, University of Miami (PAB), Miami, Florida; Department of Pathology, \\ Massachusetts General Hospital (GYL), Boston, Massachusetts; Department of Pathology, Mayo Clinic \\ (KPB), Rochester, Minnesota; Department of Pathology, University of Kiel (GK), Kiel, Germany; and \\ Department of Pathology, Memorial Sloan-Kettering Cancer Center (DSK), New York, New York
}

Lymphoepithelial cyst (LEC) of the pancreas is a rare lesion of undetermined pathogenesis that had been documented almost exclusively in males. The literature on this entity is limited to reports of single or small numbers of cases. Here is presented a clinicopathologic analysis of 12 patients with LEC, 4 of whom were female. The mean age of the patients was 56 years. Four patients presented with abdominal pain and nausea, but in two patients, the cysts were detected incidentally. Only one patient had a history of chronic pancreatitis, and another had a family member with pancreatic cancer. In one patient, a clinical diagnosis of pseudocyst was rendered, and the remaining patients were clinically thought to have cystic neoplasms. None of the patients had any identifiable immunosuppression, HIV positivity, autoimmune disorder (such as Sjogren syndrome) or lymphoma. Seven cysts were located in the head of the pancreas, and 5 were in the tail. The mean size was $4.8 \mathrm{~cm}$ (range, 1.2-17 cm). Five LECs were multilocular, three were unilocular; in others, the number of loculi was not recorded. All were "macrocystic" lesions. Two patients had two separate lesions, both in the tail of the pancreas. Histologically, all cases were characterized by cysts, some containing keratin, and lined by mature stratified squamous epithelium surrounded by dense lymphoid tissue, often with prominent follicles. In some areas, the lining epithelium had more cuboidal, flattened, or transitional appearance. Mucinous goblet-like cells were seen in one case. Acute inflammation was not seen.

Copyright (C) 2002 by The United States and Canadian Academy of Pathology, Inc

VOL. 15, NO. 5, P. 492, 2002 Printed in the U.S.A.

Date of acceptance: January 30, 2002.

Address reprint requests to: N. Volkan Adsay, M.D., Department of Pathology, Harper Hospital, 3990 John R Street, Detroit, MI 48201; e-mail: adsayv@med.wayne.edu; fax: 313-745-9299.
Four cases contained solid lymphoepithelial islands, a feature not previously described in LECs. No squamous metaplasia was identified in the uninvolved pancreatic tissue and no epithelial elements were identified in peripancreatic lymph nodes. In summary, LEC of the pancreas is a rare but distinctive lesion that may be seen in the tail of the organ where most cystic pancreatic neoplasms are encountered. In contrast to the impression from the literature, LECs may also develop in females and, therefore, should be considered in the clinical differential diagnosis of mucinous cystic neoplasms that affect a similar age group. LECs are not associated with the clinical syndromes that are seen with their analogues in the salivary glands.

KEY WORDS: Cysts, Lymphoepithelial, Pancreas. Mod Pathol 2002;15(5):492-501

Cystic lesions of the pancreas are relatively rare (1-3), but they constitute an important category with a challenging differential diagnosis at the clinical, radiological, and pathologic levels. In the past decade, wider application of radiographic techniques, coupled with the improvement in the surgical approach to this organ, has brought new attention to the cystic processes in the pancreas. As more cases of pancreatic cysts are being diagnosed and operated on, new clinicopathologic entities are being recognized (4-6), and the old ones are becoming better characterized (7-10).

Pseudocysts are the most common cystic lesions of the pancreas and usually occur as a complication of pancreatitis (11). True cysts, on the other hand, are most often neoplastic (1). The classification and understanding of these neoplastic pancreatic cysts have progressively improved in the last three decades. The serous and mucinous cystic neoplasms (SCN and MCN) described by Compagno and Oer- 
tel in the late 1970 s $(12,13)$ are now wellestablished entities. In the last two decades, intraductal neoplasms that present as cystic masses have received considerable attention in the literature $(4,14,15)$. Two such entities, intraductal papillary mucinous neoplasms (IPMN) and intraductal oncocytic papillary mucinous neoplasms (IOPN), are now well recognized (2-6). Whereas the majority of SCNs are benign (16), MCNs, IPMNs, and IOPNs may be associated with invasive carcinomas $(1,10)$. Therefore, it is crucial to distinguish these tumors from other cystic neoplasms.

Lymphoepithelial cysts (LECs) in the pancreas are relatively poorly recognized. They are reported in the literature mostly as individual case studies (17-53). The frequency of LEC in relation to other pancreatic cysts is largely unknown, and their clinical and pathologic features have not yet been fully characterized. Moreover, the pathogenesis and relationship to LECs of the salivary glands or other cystic pancreatic lesions are poorly understood.

In this study, the clinicopathologic characteristics of 11 cases of LEC in the pancreas are analyzed, its differential diagnosis from other cystic lesions is discussed, and possible pathogenetic mechanisms are reviewed.

\section{MATERIALS AND METHODS}

In a review of 154 cystic pancreatic lesions (64 true cysts and 90 pseudocysts) in the files of Karmanos Cancer Institute and Wayne State University, 4 cases of LECs were identified. Also reviewed were 134 consecutive true cystic tumors in the files of Memorial Sloan-Kettering Cancer Center between the years of 1983-1998 that did not reveal any LEC. Two cases were identified in the files of the Miami University School of Medicine. Six additional cases were culled from the consultation files of three authors (NVA, DSK, and GK). Pathology material and the charts of these patients were reviewed. A case of an epidermoid cyst in an intrapancreatic accessory spleen was also identified and was excluded from the study.

\section{RESULTS}

\section{Clinical Findings}

Eight patients were male and 3 were female. The mean age was 56 years (range, 39-82 y). All four female patients were under the age of 50 years. The tumors were located in the head or body in 4 and in the tail in 8 . The chief complaint at presentation was abdominal or back pain in 4 patients and nausea and vomiting in 1 . In 3 patients, the tumors were detected incidentally during work-up for other unrelated disorders. In the remaining 4 , this infor- mation was not available. One patient had a history of pancreatitis, and another had a family history of pancreatic cancer. In 1 patient, a clinical diagnosis of pseudocyst was given, and the remaining patients were believed to have cystic neoplasms. In all patients, the presence of a cystic pancreatic mass was discovered with various radiologic studies, mostly computed tomography. Cyst aspiration was not performed in any of the cases. All patients underwent partial pancreatectomy.

The findings in these cases are summarized in Table 1, together with the cases reported previously in the literature.

\section{Pathologic Findings \\ Macroscopic findings}

The mean size of the tumors was $4.8 \mathrm{~cm}$ (range, $1.2-17 \mathrm{~cm}$ ). In 4 patients, the findings were clearly intrapancreatic; in the remaining 8 , it was difficult to determine whether the lesions were peri- or intra-pancreatic. In 2 patients, there appeared to be two separate cysts. In both, the tumors were in the tail of the pancreas. The cysts were round and were filled with cheesy, granular, brown-yellow contents in 5 cases. In 3 cases, the cysts contained thick serous fluid instead of the keratinaceous debris (Fig. 1). The nature of the cyst contents was not specified in the remaining 4 patients. The cysts were unilocular in 3, multilocular in 3 , and bilocular in 1 patient; the number of loculi was not mentioned in the remaining 5 . The thickness of the wall of the cyst ranged from $0.2-0.6 \mathrm{~cm}$. The inner surfaces of the cysts were granular but devoid of any prominent projections. Uninvolved pancreatic tissue was unremarkable.

\section{Microscopic findings}

In all cases, the cysts had a squamous lining and a dense subepithelial rim of lymphoid tissue (Fig. $2-3$ ). In four cases, the lining was focally attenuated. In some foci, the epithelium appeared transitional (Fig. 4), and in others, flat (Fig. 5) or cuboidal. Columnar mucinous cells with features of goblet cells were detected in only one of the cases, forming a single layer at the luminal surface of otherwise squamous epithelium. In one case, a minute focus of sebaceous differentiation of the epithelium was noted. Typically, there was no intervening stroma between the epithelium and the lymphoid band; however, in two cases, focally, the lymphoid tissue was markedly thinned, leaving a thin band of fibrous tissue remaining between the cyst lining and peri-pancreatic adipose tissue (Fig. 5). Intraluminal keratin was evident and formed laminated layers in some areas (Fig. 6).

Invariably, the lymphoid tissue was composed of elements ordinarily present in lymph nodes: scat- 


\begin{tabular}{|c|c|c|c|c|c|c|}
\hline & Age & Sex & Shape & Size & Location & Clinical Finding \\
\hline Anagnostopoulos ${ }^{56}$ & 42 & M & Uni & 4.3 & $\mathrm{~T}$ & Asymptomatic \\
\hline Bastens $^{25}$ & 66 & $\mathrm{~F}$ & Uni & 4 & $\mathrm{H}$ & Abdominal mass, weight loss \\
\hline Bolis $^{26}$ & 64 & $\mathrm{M}$ & $\mathrm{N} / \mathrm{A}$ & N/A & $\mathrm{H}$ & Gastrointestinal complaints \\
\hline Cappellari $^{27}$ & 44 & $\mathrm{M}$ & Uni & 6 & $\mathrm{H}$ & LUQ abdominal pain, back pain \\
\hline Centeno $^{24}$ & 47 & $\mathrm{M}$ & Uni & 2 & $\mathrm{~T}$ & Nausea, abdominal pain \\
\hline Chan $^{23}$ & 47 & $\mathrm{M}$ & $\mathrm{M}$ & 5 & $\mathrm{H}$ & Back pain \\
\hline De Lorenzi ${ }^{28}$ & 59 & $\mathrm{M}$ & $\mathrm{N} / \mathrm{A}$ & N/A & $\mathrm{H}$ & N/A \\
\hline DiCorato $^{29}$ & 43 & $\mathrm{M}$ & Uni & 3 & $\mathrm{~T}$ & $\mathrm{~N} / \mathrm{A}$ \\
\hline Eriguchi $^{58}$ & 43 & $\mathrm{M}$ & N/A & 7.0 & $\mathrm{H}$ & Asymptomatic \\
\hline Fitko $^{30}$ & 60 & M & Uni & 4.5 & $\mathrm{~B}$ & Epigastric pain, periumbilical pain \\
\hline Fujiwara ${ }^{57}$ & 60 & M & & 4 & $\mathrm{~T}$ & Asymptomatic \\
\hline Fukukura 31 & 70 & M & Uni & 10 & $\mathrm{~T}$ & N/A \\
\hline Fukukura ${ }^{31}$ & 74 & M & M & 4 & $\mathrm{~B}$ & Cholelithiasis \\
\hline $\mathrm{Gafa}^{32}$ & 57 & M & Uni & 2.5 & $\mathrm{H}$ & Abdominal pain \\
\hline Goodman $^{33}$ & 68 & $\mathrm{M}$ & $\mathrm{M}$ & 10 & $\mathrm{~B}$ & Abdominal pain, nausea, vomiting \\
\hline Hausegger ${ }^{34}$ & N/A & $\mathrm{M}$ & Uni & 5 & $\mathrm{~T}$ & N/A \\
\hline Hisaoka $^{35}$ & 65 & $\mathrm{M}$ & $\mathrm{M}$ & 5 & $\mathrm{~B}$ & $\mathrm{~N} / \mathrm{A}$ \\
\hline Iacono $^{36,70}$ & 56 & M & Uni & 3.5 & $\mathrm{~B}$ & Epigastric pain \\
\hline Kaiserling $^{37}$ & 53 & $\mathrm{M}$ & $\mathrm{M}$ & 8 & $\mathrm{~T}$ & Fatigue \\
\hline $\mathrm{Katz}^{38}$ & 42 & $\mathrm{~F}$ & $\mathrm{M}$ & 2.5 & $\mathrm{H}$ & Lower back pain, abdominal pain, fever, chills \\
\hline Kazumori $^{39}$ & 48 & $\mathrm{M}$ & M & 2.5 & $\mathrm{~T}$ & General fatigue \\
\hline $\mathrm{Kim}^{40}$ & $\mathrm{~N} / \mathrm{A}$ & $\mathrm{M}$ & $\mathrm{N} / \mathrm{A}$ & N/A & $\mathrm{N} / \mathrm{A}$ & $\mathrm{N} / \mathrm{A}$ \\
\hline $\mathrm{Koga}^{41}$ & 56 & $\mathrm{M}$ & M & 3 & $\mathrm{H}$ & $\mathrm{N} / \mathrm{A}$ \\
\hline $\operatorname{Koga}^{41}$ & 62 & $\mathrm{M}$ & $\mathrm{M}$ & 8 & $\mathrm{H}$ & $\mathrm{N} / \mathrm{A}$ \\
\hline $\mathrm{Liu}^{22}$ & 49 & $\mathrm{M}$ & Uni & 7.5 & $\mathrm{~T}$ & Recurrent abdominal pain \\
\hline $\mathrm{Liu}^{22}$ & 56 & $\mathrm{M}$ & Uni & $\mathrm{N} / \mathrm{A}$ & $\mathrm{T}$ & $\begin{array}{l}\text { Vague abdominal pain, nausea, vomiting, loose } \\
\text { stool }\end{array}$ \\
\hline Luchtrath $^{53}$ & 36 & M & N/A & & $\mathrm{B}$ & Weight loss \\
\hline Mandavilli $^{21}$ & 49 & $\mathrm{~F}$ & $\mathrm{~N} / \mathrm{A}$ & 6 & $\mathrm{~B}$ & Vague epigastric abdominal pain \\
\hline Mitchell $^{42}$ & 42 & M & M & 6 & $\mathrm{H}$ & Fever, malaise, RUQ abdominal pain \\
\hline Mockli $^{43}$ & 72 & $\mathrm{M}$ & $\mathrm{Bi}$ & 4 & $\mathrm{~T}$ & Mitral and aortic valve prosthesis \\
\hline Ramsden ${ }^{44}$ & 73 & M & Uni & 2 & $\mathrm{~B}$ & Asymptomatic \\
\hline Rino $^{45}$ & 58 & M & $\mathrm{M}$ & 5 & $\mathrm{H}$ & $\mathrm{N} / \mathrm{A}$ \\
\hline Sako $^{19}$ & 75 & $\mathrm{~F}$ & N/A & 0.5 & $\mathrm{~N} / \mathrm{A}$ & Incidental \\
\hline Sako $^{19}$ & 57 & $\mathrm{~F}$ & N/A & 0.8 & N/A & Incidental \\
\hline Sako $^{19}$ & 57 & $\mathrm{~F}$ & $\mathrm{~N} / \mathrm{A}$ & N/A & N/A & None \\
\hline Sako $^{19}$ & 75 & $\mathrm{~F}$ & $\mathrm{~N} / \mathrm{A}$ & N/A & $\mathrm{H}$ & None \\
\hline Schinke-Nickl ${ }^{46}$ & 59 & $\mathrm{~N} / \mathrm{A}$ & $\mathrm{N} / \mathrm{A}$ & 6 & $\mathrm{H}$ & Diarrhea, abdominal pain \\
\hline Schwarz ${ }^{18}$ & 54 & M & N/A & N/A & $\mathrm{T}$ & Chronic back pain \\
\hline Shigemori ${ }^{59}$ & 63 & $\bar{M}$ & $\mathrm{~N} / \mathrm{A}$ & $\mathrm{N} / \mathrm{A}$ & $\mathrm{H}, \mathrm{T}$ & Back pain \\
\hline Strapko $^{47}$ & 42 & $\mathrm{~F}$ & $\mathrm{M}$ & & $\mathrm{B}$ & Lower back pain, abdominal pain, fever, chills*** \\
\hline Tateyama ${ }^{17}$ & 59 & $\mathrm{M}$ & $\mathrm{M}$ & 5 & $\mathrm{~T}$ & Annual checkup \\
\hline Truong ${ }^{48,49}$ & 35 & $\mathrm{M}$ & Uni & 6 & B & Diarrhea, abdominal pain \\
\hline Truong ${ }^{48,49}$ & $\mathrm{~N} / \mathrm{A}$ & N/A & N/A & N/A & $\mathrm{N} / \mathrm{A}$ & N/A \\
\hline Truong 48,49 & N/A & N/A & N/A & N/A & $\mathrm{N} / \mathrm{A}$ & N/A \\
\hline Truong ${ }^{48,49}$ & $\mathrm{~N} / \mathrm{A}$ & N/A & N/A & N/A & N/A & $\mathrm{N} / \mathrm{A}$ \\
\hline Truong 48,49 & $\mathrm{~N} / \mathrm{A}$ & N/A & N/A & $\mathrm{N} / \mathrm{A}$ & $\mathrm{N} / \mathrm{A}$ & N/A \\
\hline Tsuchiya $^{54}$ & 50 & M & $\mathrm{M}$ & $2,4.5$ & $\mathrm{H}, \mathrm{B}$ & Asymptomatic \\
\hline Ueno $^{50}$ & N/A & M & Uni & 3 & $\mathrm{~B} 0$ & Abdominal pain \\
\hline Widgren $^{51}$ & 46 & N/A & N/A & N/A & B & N/A \\
\hline Worrall $^{55}$ & 61 & $\mathrm{M}$ & $\mathrm{M}$ & 7.5 & $\mathrm{H}$ & $\begin{array}{l}\text { Epigastric abdominal pain, malaise, fever, } \\
\text { constipation, abdominal distension }\end{array}$ \\
\hline Yamaguchi ${ }^{60}$ & 57 & $\mathrm{~F}$ & $\mathrm{~N} / \mathrm{A}$ & N/A & N/A & None \\
\hline Yamamoto $^{52}$ & 64 & $\mathrm{M}$ & M & 4 & B & $\mathrm{N} / \mathrm{A}$ \\
\hline Case 1 & 45 & $\mathrm{M}$ & M & 17 & $\mathrm{~T}$ & Fatigue, nausea, vomiting \\
\hline Case 2 & 46 & $\mathrm{~F}$ & Uni & 6 & $\mathrm{~T}$ & Abdominal pain, epigastric pain \\
\hline Case 3 & 46 & $\mathrm{~F}$ & $\mathrm{~N} / \mathrm{A}$ & 1.5 & $\mathrm{~T}$ & Left back pain, nausea, weight loss \\
\hline Case 4 & 45 & M & M & $5,3.5$ & $\mathrm{~T}$ & Abdominal pain \\
\hline Case 5 & 45 & $\mathrm{~F}$ & $\mathrm{~N} / \mathrm{A}$ & 1.2 & $\mathrm{H}$ & Incidental \\
\hline Case 6 & 59 & $\mathrm{M}$ & $\mathrm{Bi}$ & 4.5 & $\mathrm{~T}$ & Urothelial carcinoma \\
\hline Case 7 & 82 & $\mathrm{M}$ & N/A & 3 & $\mathrm{~B}$ & Right dorsal pain \\
\hline Case 8 & 74 & $\mathrm{M}$ & $\mathrm{N} / \mathrm{A}$ & 5 & B & N/A \\
\hline Case 9 & 63 & $\mathrm{M}$ & $\mathrm{M}$ & 4.5 & $\mathrm{~T}$ & $\mathrm{~N} / \mathrm{A}$ \\
\hline Case 10 & 60 & $\mathrm{M}$ & $\mathrm{U}$ & 2.5 & $\mathrm{H}$ & N/A \\
\hline Case 11 & 58 & $\mathrm{M}$ & $\mathrm{U}$ & 3.5 & $\mathrm{~T}$ & Incidental \\
\hline Case 12 & 40 & $\mathrm{~F}$ & $\mathrm{~N} / \mathrm{A}$ & 2.0 & $\mathrm{~T}$ & $\mathrm{~N} / \mathrm{A}$ \\
\hline \multirow[t]{3}{*}{64 Cases } & 55 & $\mathrm{M} / \mathrm{F}=4$ & Multi/bi: 55\% & 4.7 & $\mathrm{~T}=38 \%$ & Pain, discomfort: 21 \\
\hline & & & Uni: $45 \%$ & & $\mathrm{H}=32 \%$ & Incidental: 11 \\
\hline & & & & & $\mathrm{B}=30 \%$ & Nausea, diarrhea: 7 \\
\hline
\end{tabular}

Sex: M, male; F, female.

Shape: Uni, Unilocular; M, Multilocular; Bi, Bilocular.

Location: T, Tail; B, Body; H, Head.

N/A, Not Applicable. 


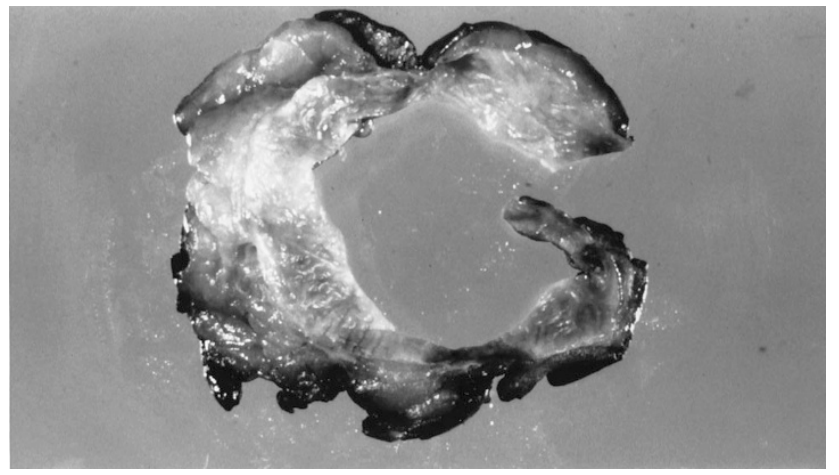

FIGURE 1. Macroscopic appearance of an LEC. The cyst in this case was unilocular. It was well demarcated and contained clear serous fluid. The cyst lining was smooth with fine granularity.

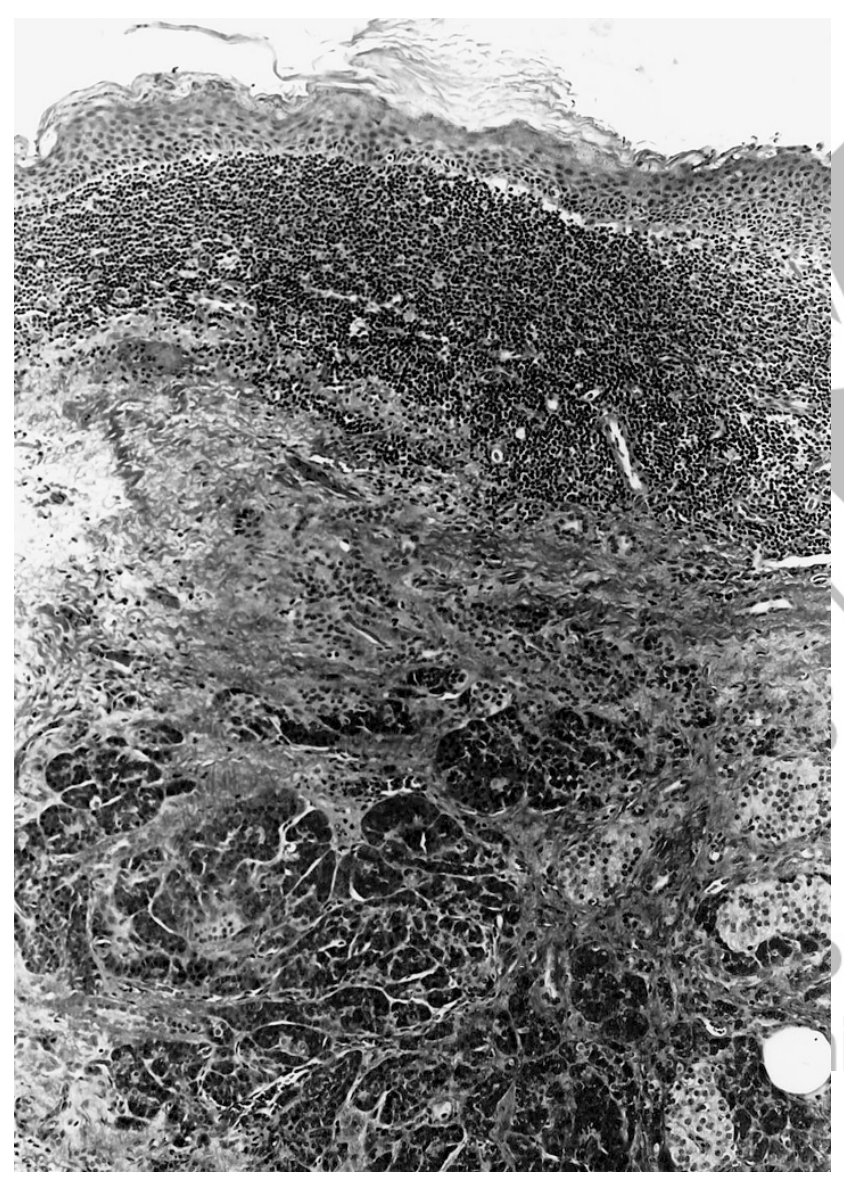

FIGURE 2. Lymphoepithelial cyst in the pancreas. Keratinizing squamous epithelium (top) is separated from the pancreas by a band of lymphoid tissue.

tered lymphoid follicles surrounded by a dense infiltrate of small round bland lymphocytes. In four cases, the lymphoid tissue was surrounded by thin fibrous capsule and a subcapsular space similar to the "subcapsular sinus" seen in lymph nodes. The lining epithelium lacked intraepithelial lymphocytes in the squamous areas; however, areas with more transitional appearance contained abundant intraepithelial lymphocytes (Fig. 4). In some areas,

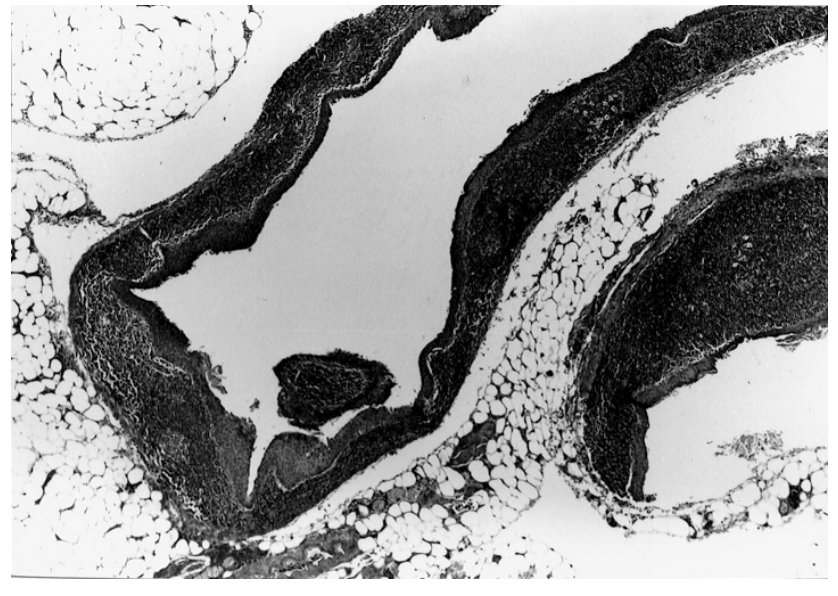

FIGURE 3. The lymphoid tissue in LECs often form a distinct band and creates the impression of a lymph node. In many cases, the lesion is surrounded by adipose tissue and appears to be peripancreatic (rather than intrapancreatic); however, careful examination often discloses pancreatic ducts or islets in this adipose tissue, indicating that it is atrophic pancreas.

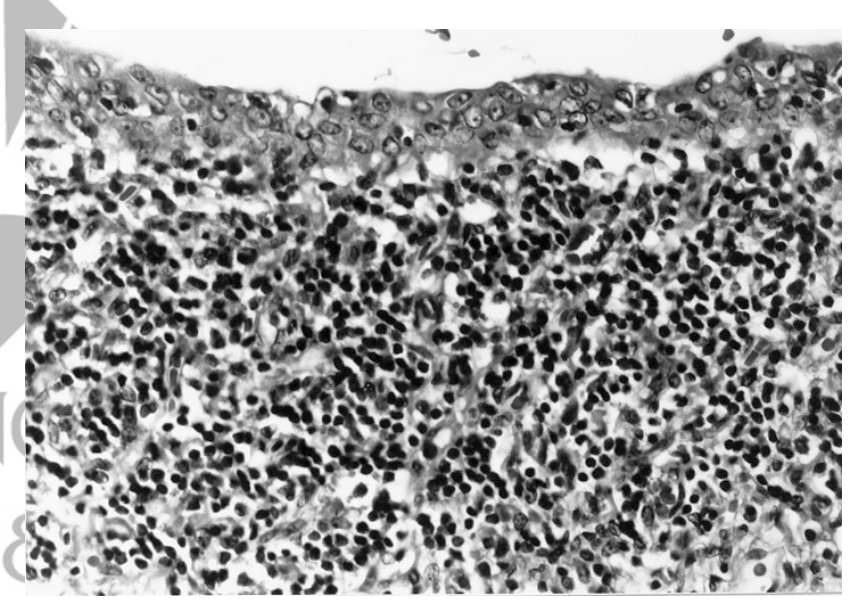

FIGURE 4. The epithelium, in some areas, has a more transitional appearance. This finding is often associated with presence of intraepithelial lymphocytes.

\section{rized Use}

there were complex, reticular invaginations of the epithelium into the lymphoid tissue, forming a nodular, papillary architecture (Fig. 7), the type that is often seen in Warthin tumor of salivary glands. In four cases, there were small lymphoepithelial nests within the lymphoid tissue with the morphologic features resembling "epimyoepithelial" islands of salivary LEC (benign lymphoepithelial lesions). There were small ductal elements with lumina associated with these epithelial nests (Fig. 8). In three cases, there were keratin granulomas (Fig. 9) and microscopic foci of fat necrosis in the lymphoid areas or in the immediately adjacent pancreas. Clusters of foamy macrophages were also seen. No squamous metaplasia was identified in the uninvolved pancreatic tissue, and no epithelial elements were identified in peripancreatic lymph nodes available for examination. 


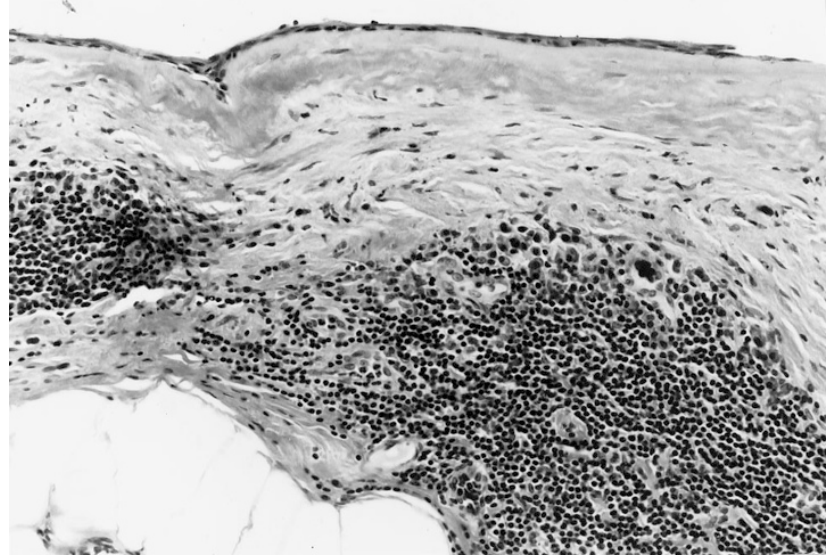

FIGURE 5. The lining epithelium is often attenuated and even denuded. This finding (atrophy) is often associated with a fibrous tissue immediately adjacent to the epithelium.

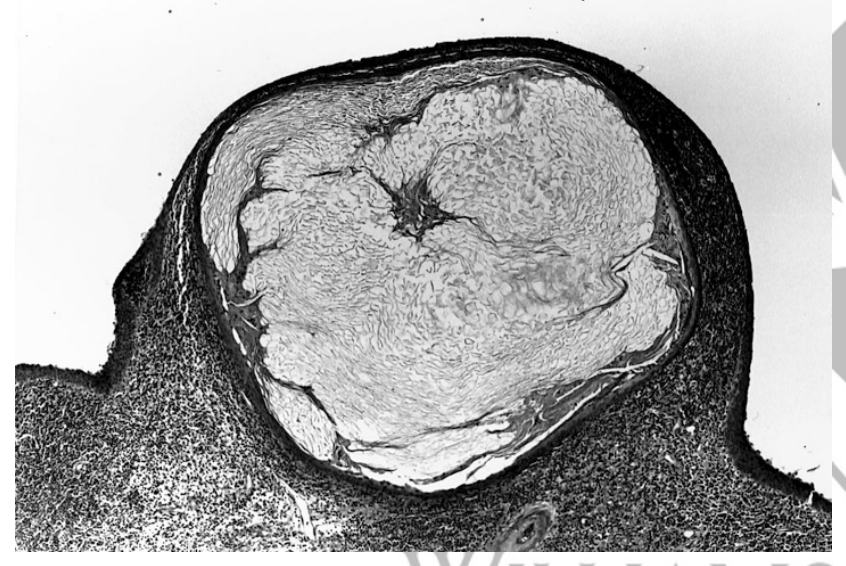

FIGURE 6. Intraluminal laminated keratin filling an invaginated segment of the cyst.

\section{DISCUSSION}

LECs of the pancreas are very rare, constituting approximately $0.5 \%$ of pancreatic cysts in the authors' experience. When the data reported in the literature (17-60) are combined with the 12 cases reported here (Table 1), the following general characteristics of LECs become apparent. They are seen in middle-aged patients (mean age, $55 \mathrm{y}$; range, 35-82 y), predominantly but not exclusively in men $(\mathrm{M} / \mathrm{F}=4 / 1)$; in contrast, earlier reports had suggested that they were seen only in men. The most common symptom at presentation is abdominal pain. Other complaints at presentation include nausea, vomiting, anorexia, weight loss, back pain, fatigue, fever, and chills. Many cases are diagnosed during a work-up for other diseases. In rare cases, there are multiple tumors (one of our patients and one reported by Tsuchiya et al.; 54).

LECs are often round and have a well-defined wall that is sharply demarcated from the pancreas and surrounding adipose tissue. The lesion often

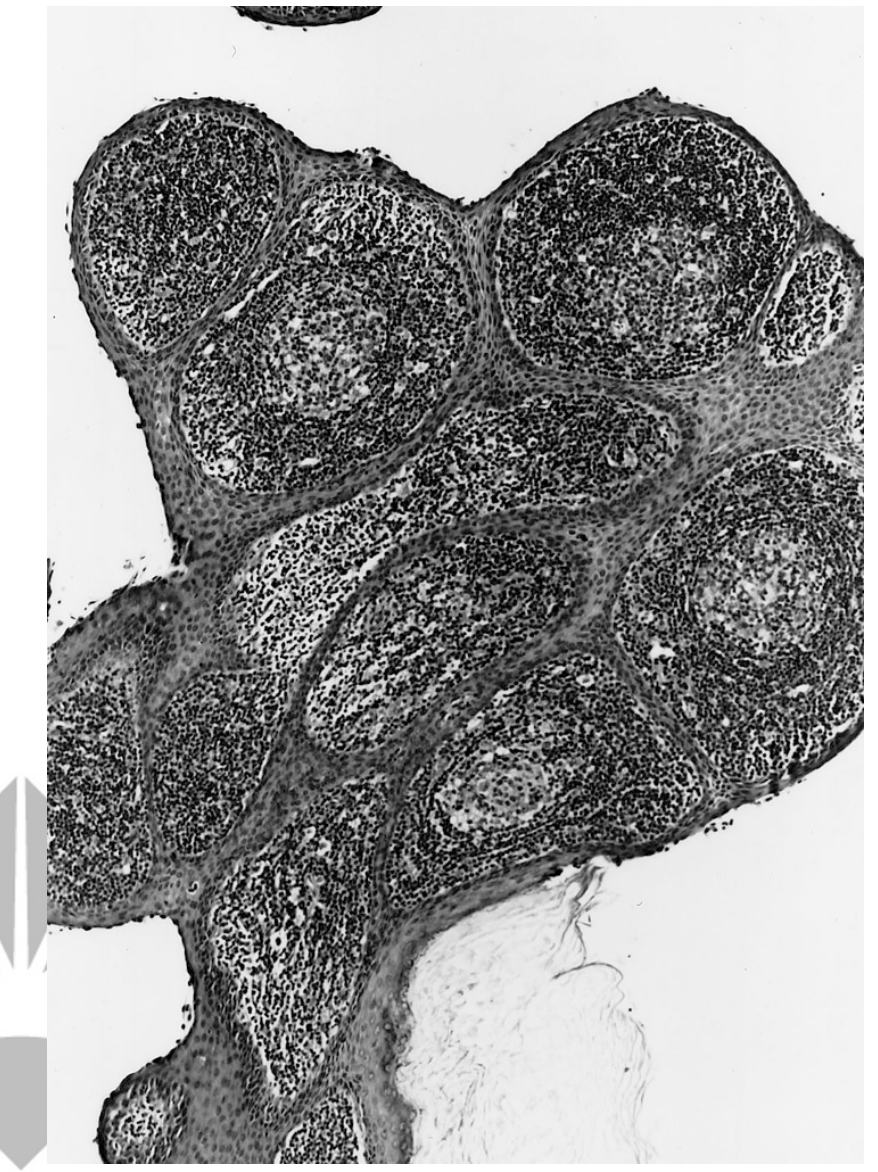

FIGURE 7. Epithelium forming complex reticular pattern that separates individual lymphoid follicles is depicted. This finding can be prominent in some areas, forming macroscopic nodularity in the cyst lining.

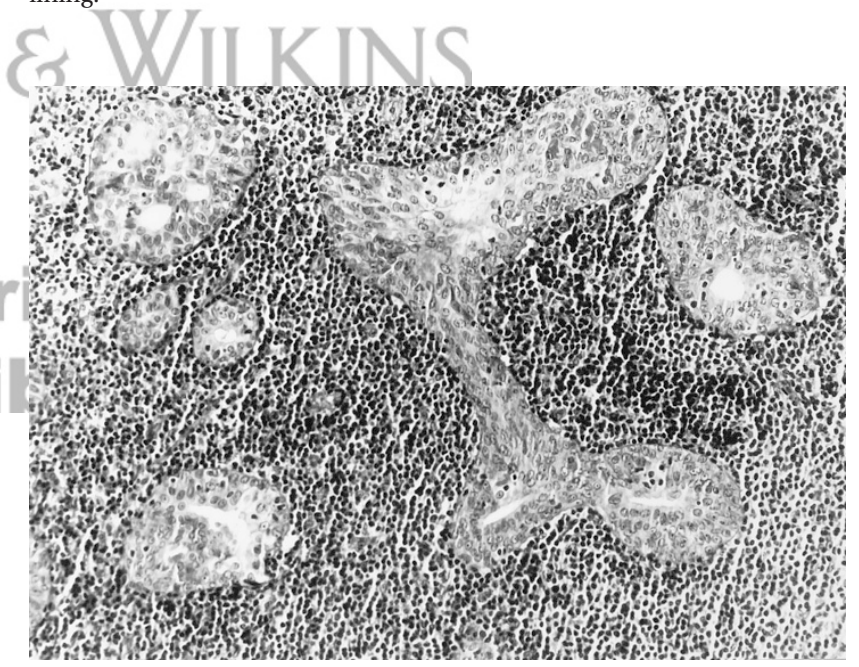

FIGURE 8. Epithelial inclusions in the lymphoid tissue were present in four cases. These focally have features reminiscent of epimyoepithelial islands. They may form ductal structures.

protrudes from the pancreatic parenchyma (31, 39, $41,46,50$ ), and many cases appear to be peripancreatic rather than intrapancreatic. The mean size of LECs is $4.6 \mathrm{~cm}$ (range, $1.2-17 \mathrm{~cm}$ ). They can be multilocular (in $60 \%$ ) or unilocular (in $40 \%$ ). LECs do not appear to have any preferential location in 


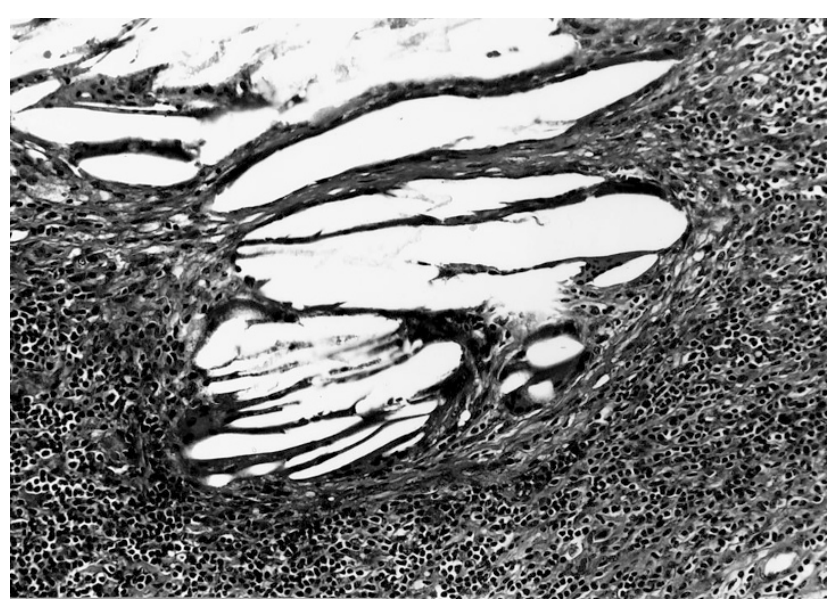

FIGURE 9. Extraluminal leakage of keratin material is associated with keratin granulomas with multinucleated giant cell reaction.

the pancreas. Cyst contents, which are mostly composed of keratin, have a different radiographic density than mucin of mucinous cystic neoplasms; however, they may be difficult to distinguish from those of pseudocysts. This is true for the macroscopic appearance as well. The cyst contents display "cheesy" or "caseous" appearance characteristic of keratinaceous debris or may be clear and serous in some cases. Microscopically, the LECs are characterized by cysts lined by stratified squamous epithelium and immediately adjacent, dense subepithelial lymphoid tissue that contains lymphoid follicles. In some areas, the lining may appear more transitional and in others, flat, cuboidal, and focally denuded. Sebaceous differentiation is reported in a small percentage of the cases $(30,57)$ and was seen in only 1 of our 12 cases, in which it was represented as a minute focus. Scattered mucinous cells have also been reported and were present in one of our cases. This was a focal finding, and the cells had goblet cell features and were forming an umbrella layer over the stratified squamous epithelium. The presence of a significant sebaceous or prominent mucinous component should favor the diagnosis of a dermoid cyst.

The cyst wall and trabeculae in LECs contain dense lymphoid tissue composed predominantly of mature $\mathrm{T}$ lymphocytes and intervening germinal centers that contain B cells. Follicular architecture may be prominent in some cases. In some areas, the lymphoid tissue is exuberant but interrupted by complex invaginations of the epithelium, imparting a papillary appearance that may be responsible for the nodularity in the inner surfaces of the cysts. There are usually no significant numbers of lymphocytes within the epithelium. Solid lymphoepithelial islands (microscopic clusters of epithelial cells admixed with lymphocytes, akin to the socalled "epimyoepithelial islands" in the salivary glands LECs) may be present but are rare. It is uncommon for LECs to exhibit marked acute inflammation; however, the adjacent pancreas and the lymphoid tissue may show granulomas, especially keratin granulomas with foreign-body giant cells and foamy histiocytes. The latter may form multiple nodules around the tumor. Fat necrosis may also be seen, possibly secondary to the reaction of a ruptured cyst's contents with peripancreatic fat.

The clinical differentiation of LECs from other cystic lesions of the pancreas can be challenging. LECs have a macrocystic appearance and are thus clearly distinguished from microcystic lesions such as serous microcystic adenoma. Their distinction from macrocystic ("megacystic") lesions at clinical level could be problematic. Chemical analysis of aspirated cyst fluid has proven to be useful in the differential diagnosis of pancreatic cysts in general.

Intuitively, the traditional markers such as CEA, CA19-9, CA-125, CA72-4, pS2, mucin-like carcinoma-associated antigen, and fluid viscosity would be expected to be significantly lower in LECs than in mucinous neoplasms $(1,61,63)$; however, the limited experience in LECs does not confirm this prediction $(24,28,37,54)$. Some cases had high CA19-9 levels in the cyst but not in the serum (23, 37). This is an interesting finding considering that squamous metaplasia in pancreatic ductal epithelium is often immunohistochemically negative for these markers. Radiologic tests may not be specific either. The main radiographic finding that may help distinguish LEC is that it is sharply demarcated from the pancreatic tissue $(31,39,41,46,50)$. Some authors have found selective angiography to be particularly helpful in the diagnosis (45).

The most clinically significant differential diagnosis of LEC is with the primary neoplastic cysts of the pancreas: mucinous cystic neoplasms (7-10), intraductal papillary mucinous neoplasms $(4,5$, 15), and intraductal oncocytic papillary mucinous neoplasms (6). It is very uncommon for these tumors to have a lymphoid reaction, and often such changes are limited in degree and do not form a sub-pithelial band as seen in LECs. Furthermore, papillary changes are not seen in LECs, and mucinous cells are very uncommon. The differential diagnosis of LECs from the rare cystic examples of typically solid pancreatic tumors (solid pseudopapillary tumors, ductal adenocarcinomas with cystic change, cystic islet cell tumors, and acinar cell cystadenocarcinoma; 64, 65) may potentially be a challenge at clinical level; however, pathologically, these can be easily distinguished by their characteristic histomorphologic features.

The microscopic differential diagnosis of LECs is mainly with dermoid cysts, epidermoid cysts in intrapancreatic accessory spleens, lymphangiomas, and pseudocysts. Dermoid cysts (DCs; 66-85) and 
epidermoid cyst in intrapancreatic accessory spleen (ECISs; 86-94) share various clinical and pathologic features with LECs. The following characteristics may help distinguish them. DCs and ECISs tend to be detected in younger age groups (mean ages, 29 and $37 \mathrm{y}$, respectively) than LECs (mean age, $55 \mathrm{y}$ ). It should be noted here that many cases that have been reported as DC in the past may now be classified as LECs $(66,67)$. There is no gender predominance in DCs and ECISs, whereas LECs are seen more often in men.

Microscopically, LECs are lined almost exclusively by squamous epithelium, although it is sometimes denuded, attenuated, and may become cuboidal with a transitional appearance. Sebaceous-type changes and mucinous cells are exceedingly rare, and if present, are very focal. The presence of mucinous cells and especially respiratory-type mucosa would be more indicative of DC. Subepithelial dense lymphoid tissue admixed with germinal centers is characteristic of LECs, and the presence of splenic red pulp is diagnostic of ECISs. Infection and suppurative inflammation are frequent complications of DCs but are rarely seen in LECs. Unless there is extensive sebaceous differentiation, hair follicle, respiratory mucosa, or other teratomatous elements, squamous lined cysts with subepithelial rim of dense lymphoid tissue of nonsplenic type should be classified as LEC. Because none of these lesions have any known malignant potential, their differentiation from each other may not be as important as their differentiation from other cystic lesions of the pancreas.

Lymphangiomas (95) may also present as pancreatic and peripancreatic cystic masses and may closely mimic LECs (especially those with denuded epithelium) because they also contain prominent lymphoid tissue, often with follicles. Immunohistochemical stains with endothelial markers and keratins are helpful in confirming the diagnosis in doubtful cases.

Pseudocysts are postnecrotic cystic changes (11) seen in patients with pancreatitis. They are also peripancreatic. They lack the dense lymphoid tissue and squamous lining; however, in the areas of LECs where the epithelium is denuded, or in those LECs with fat necrosis and keratin granulomas, the "dirty" appearance may be mistaken for a pseudocyst. LECs seldom have acute inflammatory changes and granulation tissue that are seen in pseudocysts.

The etiopathogenesis of LECs is not known. Conditions that are typically associated with LEC of salivary glands, such as a history of Sjogren disease, HIV infection, or lymphoma have not been recorded in pancreatic LECs.

A proposed mechanism of pathogenesis for LECs is the development from epithelial remnants in lymph nodes $(35,96)$. In fact, Arai et al. (96) have identified what may be LEC precursors in the peripancreatic lymph nodes (19). Furthermore, there are also examples of LECs that occur in the intrabdominal lymph nodes $(97,98)$. The puzzling aspects about this possibility are the following: (1) such epithelial remnants are detected exceedingly rarely (48), even more so than the LECs; (2) some LECs lack the characteristic features of a lymph node, such as sinuses and a capsule, and (3) although most LECs are predominantly peripancreatic, others appear to be situated within the organ itself, and unlike the parotid glands, intraglandular lymph nodes are exceedingly uncommon in the pancreas. Nevertheless, this hypothesis is quite appealing. The presence of small ductal elements in the lymphoid tissue of four cases in this study may lend further support to this hypothesis.

It is unlikely that mesothelial invaginations, favored hypothesis of the splenic epidermoid cysts, would apply to LECs of the pancreas.

Cystic transformation of pancreatic ducts that had undergone squamous metaplasia has been considered (49). Although this is a possibility, squamous metaplasia in the uninvolved pancreatic tissue, which would have supported this hypothesis, is a relatively uncommon finding in the pancreas and was not noted in any of the cases presented here. Also, this hypothesis, by itself, would not explain the degree and pattern of lymphoid tissue.

It has also been suggested that LECs may be a form of teratoma; however, the presence and the distribution of lymphoid tissue would be most unusual for/a teratoma. Furthermore, mucinous epithelium and sebaceous cells, which are common findings in teratomas, are seldom reported in LECs and were not detected in any of our cases except for one that displayed a minute focus of sebaceous metaplasia.

It has also been speculated that LECs may represent branchial cleft cysts that have been displaced and fused with the pancreas during embryogenesis $(48,53)$.

One hypothesis that is quite appealing is a continuation of a mechanistic explanation unifying those head and neck lesions that are characterized by cystic or glandular epithelial elements surrounded by lymphoid tissue (namely LECs, Warthins tumors, and some branchial cleft cysts) into one generic category. It is speculated that these lesions may be driven by lymphoid cells with affinity for ductal epithelia and the capacity to induce their growth by the factors they mediate (Juan Rosai, M.D., personal communication, May 1995). The type of the lining epithelium then may be a factor of antigens present in different types of ductal tissue to which these lymphocytes are attracted.

No recurrences or progression into lymphoma or carcinoma have been documented in the cases of 
LECs in which follow-up information was available. Therefore, if the tumor can be diagnosed preoperatively, the option of "wait and watch" may be clinically acceptable. However, in most cases, the possibility of another type of pancreatic cystic neoplasm is difficult to rule out with the current investigative methods. Also, because LECs are often well delineated from the pancreatic parenchyma, they may seem amenable to cystectomy; however, before such an operation can be attempted, the diagnosis needs to be confirmed because this would be suboptimal therapy for most other macrocystic neoplasms.

As the list of the differential diagnosis of cystic pancreatic lesions grows, so does the importance of characterization and recognition of the various entities that form this differential. LECs, although rare, comprise an important category in this differential diagnosis. [62]

Acknowledgments: The authors thank Ben True for his expertise in photography and Tierra Munn and Cheryl Lubinski for their assistance in the preparation of this manuscript.

\section{REFERENCES}

1. Adsay NV, Klimstra DS, Compton CC. Cystic lesions of the pancreas. Semin Diagn Pathol 2000;17:1-6.

2. Kloppel G, Solcia E, Longnecker DS, Capella C, Sobin LH. World Health Organization international histologic classification of tumors. Histologic typing of tumors of the exocrine pancreas. In: World Health Organization -international histologic classification of tumors. Vol 2. Geneva, Switzerland: Springer; 1996.

3. Solcia E, Capella C, Kloppel G. Tumors of the pancreas. In: Armed Forces Institute of Pathology atlas of tumor pathology. Vol 20. Washington, DC: American Registry of Pathology; 1997. p. 53-64.

4. Kloppel G. Clinicopathologic view of intraductal papillarymucinous tumor of the pancreas. Hepatogastroenterology 1998;45:1981-5.

5. Adsay NV, Longnecker DS, Klimstra DS. Pancreatic tumors with cystic dilatation of the ducts: intraductal papillary mucinous neoplasm and intraductal oncocytic papillary neoplasms. Semin Diagn Pathol 2000;17:16-31.

6. Adsay NV, Adair CF, Heffess CS, Klimstra DS. Intraductal oncocytic papillary neoplasms of the pancreas. Am J Surg Pathol 1996;20:980-94.

7. Thompson LDR, Becker RC, Pryzgodski RM, Adair CF, Heffess C. Mucinous cystic neoplasm (mucinous cystadenocarcinoma of low malignant potential) of the pancreas: a clinicopathologic study of 130 cases. Am J Surg Pathol 1999;23: $1-16$.

8. Zamboni G, Scarpa A, Bogina G, Iacono C, Bassi C, Talamini $\mathrm{G}$, et al. Mucinous cystic tumors of the pancreas: clinicopathological features, prognosis, and relationship to other mucinous cystic tumors. Am J Surg Pathol 1999;23:410-22.

9. Wilentz RE, Talamani MA, Albores-Saavedra J, Hruban RH. Morphology accurately predicts behavior of mucinous cystic neoplasms of the pancreas. Am J Surg Pathol 1999;23:1320-7.
10. Wilentz RE, Albores-Saavedra J, Hruban RH. Mucinous cystic neoplasms of the pancreas. Semin Diagn Pathol 2000;17: 31-43.

11. Kloppel G. Pseudocysts and other non-neoplastic cysts of the pancreas. Semin Diagn Pathol 2000;17:1-7.

12. Compagno J, Oertel JE. Microcystic adenomas of the pancreas (glycogen-rich cystadenomas): a clinicopathologic study of 34 cases. Am J Clin Pathol 1978;69:289-98.

13. Compagno J, Oertel JE. Mucinous cystic neoplasms of the pancreas with overt and latent malignancy (cystadenocarcinoma and cystadenoma). A clinicopathologic study of 41 cases. Am J Clin Pathol 1978;69:573-80.

14. Yanagisawa A, Ohashi K, Hori M, Takagi K, Kitagawa T, Sugano $\mathrm{H}$, et al. Ductectatic-type mucinous cystadenoma and cystadenocarcinoma of the human pancreas: a novel clinicopathological entity. Jpn J Cancer Res 1993;84:474-9.

15. Sessa F, Solcia E, Capella C, Bonato M, Scarpa A, Zamboni G, et al. Intraductal papillary-mucinous tumours represent a distinct group of pancreatic neoplasms: an investigation of tumour cell differentiation and K-ras, p53 and c-erbB-2 abnormalities in 26 patients. Virchows Arch 1994;425:357-67.

16. Compton CC. Serous cystic tumors of the pancreas. Semin Diagn Pathol 2000;17:43-56.

17. Tateyama H, Tada T, Murase T, Fujitake S, Eimoto T. Lymphoepithelial cyst and epidermoid cyst of the accessory spleen in the pancreas. Mod Pathol 1998;11:1171-7.

18. Schwarz RE, Weiss LM. Lymphoepithelial cyst of the pancreas. No evidence for Epstein-Barr virus-related pathogenesis. Int J Pancreatol 1999;25:223-7.

19. Sako S, Isozaki H, Hara H, Tsutsumi A, Tanigawa N. Cystic lymphoepithelial lesions of the pancreas and peripancreatic region: report of two cases. Surg Today 1999;29:467-71.

20. Miyazaki J, Nakazawa S, Yoshino J, Inui K, Okushima K, Nakamura Y, et al. A case of lymphoepithelial cyst of the pancreas. Nippon Shokakibyo Gakkai Zasshi 1999;96:550-7.

21. Mandavilli SR, Port J, Ali SZ. Lymphoepithelial cyst (LEC) of the pancreas: cytomorphology and differential diagnosis on fine-néedle aspiration (FNA). Diagn Cytopathol 1999;20:371-4

22. Liu J, Shin HJ, Rubenchik I, Lang E, Lahoti S, Staerkel GA. Cytologic features of lymphoepithelial cyst of the pancreas: two preoperatively diagnosed cases based on fine-needle aspiration. Diagn Cytopathol 1999;21:346-50.

23. Chan SP, Hatton CW, Falk GL. Lymphoepithelial cyst of the pancreas: serum markers do not help. HPB Surg 1998;11: 121-4.

24. Centeno BA, Stockwell JW, Lewandrowski KB. Cyst fluid cytology and chemical features in a case of lymphoepithelial cyst of the pancreas: a rare and difficult preoperative diagnosis. Diagn Cytopathol 1999;21:328-30.

25. Bastens B, Golaire M, Cappelli J, Lamy V, Dryjski J, Moisse R. Lymphoepithelial cyst of the pancreas. Gastroenterol Clin Biol 1992;16:808-10.

26. Bolis GB, Farabi R, Liberati F, Maccio T. Lymphoepithelial cyst of the pancreas. Report of a case diagnosed by fine needle aspiration biopsy. Acta Cytol 1998;42:384-6.

27. Cappellari JO. Fine-needle aspiration cytology of a pancreatic lymphoepithelial cyst. Diagn Cytopathol 1993;9:77-81.

28. De Lorenzi D, Candinas D, Flury R, Meyenberger C, Largiader F. Lymphoepithelial cyst of the pancreas. Helvetica Chir Acta 1993;60:131-5.

29. DiCorato MP, Schned AR. A rare lymphoepithelial cyst of the pancreas. Am J Clin Pathol 1992;98:188-91.

30. Fitko R, Kampmeier PA, Batti FH, Benjoya RA, Rao SM. Lymphoepithelial cyst of the pancreas with sebaceous differentiation. Int J Pancreatol 1994;15:145-7.

31. Fukukura $\mathrm{Y}$, Inoue $\mathrm{H}$, Miyazono N, Kajiya $\mathrm{Y}$, Fujiyoshi F, Yano T, et al. Lymphoepithelial cysts of the pancreas: dem- 
onstration of lipid component using CT and MRI. J Comput Assist Tomogr 1998;22:311-3.

32. Gafa R, Grandi E, Cavazzini L. Lymphoepithelial cyst of the pancreas. J Clin Pathol 1997;50:794-5.

33. Goodman P, Kumar D, Balachandran S. Lymphoepithelial cyst of the pancreas. Abdom Imaging 1994;19:157-9.

34. Hausegger KW, Leitner G, Wagner C, Stangl F. Lymphoepithelial cyst of the tail of the pancreas-a case report. Rofo Fortschr Geb Rontgenstr Neuen Bildgeb Verfahr 1993;159: $200-2$.

35. Hisaoka M, Haratake J, Horie A, Yasunami Y, Kimura T. Lymphoepithelial cyst of the pancreas in a 65-year-old man. Hum Pathol 1991;22:924-6.

36. Iacono C, Cracco N, Zamboni G, Bernardello F, Zicari M, Marino F, et al. Lymphoepithelial cyst of the pancreas. Report of two cases and review of the literature. Int J Pancreatol 1996;19:71-6.

37. Kaiserling E, Seitz KH, Rettenmaier G, Seidel W, Kahlfuss R, Walz-Mattmuller R, et al. Lymphoepithelial cyst of the pancreas. Clinical, morphological, and immunohistochemical findings. Zentralbl Pathol 1991;137:431-8.

38. Katz DS, Scatorchia GM, Wojtowycz AR, Botash RJ. Lymphoepithelial cyst of the pancreatic head. AJR Am J Roentgenol 1995; 165:489.

39. Kazumori H, Sizuku T, Ueki T, Uchida Y, Yamamoto S. Lymphoepithelial cyst of the pancreas. J Gastroenterol 1997; 32:700-3.

40. Kim YH, Auh YH, Kim KW, Lee MG, Kim KS, Park SY. Lymphoepithelial cysts of the pancreas: CT and sonographic findings. Abdom Imaging 1998;23:185-7.

41. Koga H, Takayasu K, Mukai K, Muramatsu Y, Mizuguchi Y, Furukawa H, et al. CT of lymphoepithelial cysts of the pancreas. J Comput Assist Tomogr 1995;19:221-4.

42. Mitchell ML. Fine needle aspiration biopsy of peripancreatic lymphoepithelial cysts. Acta Cytol 1990;34:462-3.

43. Mockli GC, Stein RM. Cystic lymphoepithelial lesion of the pancreas. Arch Pathol Lab Med 990;114:85-7.

44. Ramsden KL, Newman J. Lymphoepithelial cyst of the pancreas. Histopathology 1991;18:267-8.

45. Rino Y, Morohoshi T, Funo K, Imada T, Yamamoto Y, Jojima $\mathrm{T}$, et al. Lymphoepithelial cyst of the pancreas: a preoperatively diagnosed case based on an aspiration biopsy. Surg Today 1995;25:1043-6.

46. Schinke-Nickl DA, Muller MF. Case report: lymphoepithelial cyst of the pancreas. Br J Radiol 1996;69:876-8.

47. Strapko A, Botash RJ, Murthy UK, Landas SK. Lymphoepithelial cyst of the pancreas: a case report and review of the literature. Dig Dis Sci 1998;43:870-4.

48. Truong LD, Rangdaeng S, Jordan PH Jr. Lymphoepithelial cyst of the pancreas. Am J Surg Pathol 1987;11:899-903.

49. Truong LD, Stewart MG, Hao H, Yutani C, Jordan PH. A comprehensive characterization of lymphoepithelial cyst associated with the pancreas. Am J Surg 1995;170:27-32.

50. Ueno S, Muranaka T, Maekawa S, Masuda Y, Ro T, Saku M, et al. Radiographic features in lymphoepithelial cyst of the pancreas. Abdom Imaging 1994;19:232-4.

51. Widgren S. A rare lymphoepithelial cyst of the pancreas. Am J Clin Pathol 1993;100:708.

52. Yamamoto K, Fujimoto K, Matsushiro T, Ota K. Lymphoepithelial cyst in the pancreas: a case report. Gastroenterol Jpn 1990;25:758-61.

53. Luchtrath H, Schriefers KH. A pancreatic cyst with features of a so-called branchiogenic cyst. Pathologe 1985;6:217-9.

54. Tsuchiya Y, Suzuki S, Sakaguchi T, Kojima Y, Okamoto K, Kurachi $\mathrm{K}$, et al. Lymphoepithelial cyst of the pancreas: report of a case. Surg Today 2000;30:856-60.

55. Worrall NK, Drebin JA. Pancreaticoduodenectomy for lymphoepithelial cyst of the pancreas. Am Surg 2000;66:732-4.
56. Anagnostopoulos PV, Pipinos II, Rose WW, Elkus R. Lymphoepithelial cyst in the pancreas: a case report and review of the literature. Dig Surg 2000;17:309-14.

57. Fujiwara H, Kohno N, Nakaya S, Ishikawa Y. Lymphoepithelial cyst of the pancreas with sebaceous differentiation. J Gastroenterol 2000;35:396-401.

58. Eriguchi N, Aoyagi S, Okuda K, Imayama H, Tamae T, Fukuda S, et al. A case of lymphoepithelial cyst of the pancreas. Kurume Med J 1999;46:195-8.

59. Shigemori C, Kihata M, Moriyama S. A case of lymphoepithelial cyst of the pancreas. J Jpn Surg Assoc 1995;56:2422-6.

60. Yamaguchi J, Saywad N, Satoh M, Wakabayashi J, Enomoto K, Mori M. An ultrastructural observation of lymphoepithelial cyst of the pancreas. J Clin Electron Microsc 1992;25:5-6.

61. Lewandrowski KB, Southern JF, Pins MR, Compton CC, Warshaw AL. Cyst fluid analysis in the differential diagnosis of pancreatic cysts. A comparison of pseudocysts, serous cystadenomas, mucinous cystic neoplasms, and mucinous cystadenocarcinoma. Annu Surg 1993;217:41-7.

62. Lewandrowski K, Lee J, Southern J, Centeno B, Warshaw A. Cyst fluid analysis in the differential diagnosis of pancreatic cysts: a new approach to the preoperative assessment of pancreatic cystic lesions. AJR Am J Roentgenol 1995;164: 815-9.

63. Yang JM, Southern JF, Warshaw AL, Lewandrowski KB. Proliferation tissue polypeptide antigen distinguishes malignant mucinous cystadenocarcinomas from benign cystic tumors and pseudocysts. Am J Surg 1996;171:129-30.

64. Adsay NV, Klimstra DS. Cystic forms of typically solid pancreatic tumors. Semin Diagn Pathol 2000;17:66-81.

65. Klimstra DS, Wenig BM, Heffess CS. Solid-pseudopapillary tumor of the pancreas: a typically cystic tumor of low malignant potential. Semin Diagn Pathol 2000;17:66-81.

66. Kraimps JL, Zins J, Levillain P, Azais O, Deleplanque G, Carretier M, et al. Dermoid cyst of the pancreas. Eur J Surg 1993;159:437-9.

67. Vermeulen BJ, Widgren S, Gur V, Meyer P, Iselin C, Rohner A. Dermoid cyst of the pancreas. Case report and review of the literature. Gastroentèrol Clin Biol 1990;14:1023-5.

68. Fernandez-Cebrian JM, Carda P, Morales V, Galindo J. Dermoid cyst of the pancreas: a rare cystic neoplasm. Hepatogastroenterology 1998;45:1874-6.

69. Micke O, Schafer U, Willich N. Persistent elevation of CA 19-9 levels in a patient with an extended retroperitoneal dermoid. Anticancer Res 1999;19:2717-20.

70. Iacono C, Zamboni G, Di Marcello R, Zicari M, Maran M, Montresor E, et al. Dermoid cyst of the head of the pancreas area. Int J Pancreatol 1993;14:269-73.

71. Iovchev II. Suppurative dermoid cyst of the pancreas. Vestn Khir Im I I Grek 1972;107:124.

72. Jentschura D, Bohrer MH, Geiger G. Para-pancreatic dermoid cyst. Chirurg 1990;61:548-9.

73. Markovsky V, Russin VL. Fine-needle aspiration of dermoid cyst of the pancreas: a case report. Diagn Cytopathol 1993; 9:66-9.

74. Dewar G, Arnold M, Li AK. Retroperitoneal dermoid presenting as an infected pancreatic cyst. Aust N Z J Surg 1990;60: 488-9.

75. Lazaro da Silva A, Moreno Junior M. Surgery of pancreatic dermoid cyst with ligature of superior mesenteric vein. Arq Gastroenterol 1984;21:183-6.

76. Pomosov DV, Shpit'ko FS, Volianiuk MA. Dermoid cyst of the pancreas in a child. Vestn Khir Im I I Grek 1973;110:92-3.

77. Mester M, Trajber HJ, Compton CC, de Camargo Junior HS, de Almeida PC, Hoover HC Jr. Cystic teratomas of the pancreas. Arch Surg 1990;125:1215-8.

78. Jacobs JE, Dinsmore BJ. Mature cystic teratoma of the pancreas: sonographic and CT findings. AJR Am J Roentgenol 1993;160:523-4. 
79. Assawamatiyanont S, King AD Jr. Dermoid cysts of the pancreas. Am Surg 1977;43:503-4.

80. Bowen B, Ros PR, McCarthy MJ, Olmsted WW, Hjermstad BM. Gastrointestinal teratomas: CT and US appearance with pathologic correlation. Radiology 1987;162:431-3.

81. Tobik S, Starzewski J, Walewski W. Case of retroperitoneal cystic teratoma simulating a pancreatic pseudocyst. Pol Przegl Chirurg 1974;46:179-81.

82. Komarov IF. Acute destructive pancreatitis in a child. Vestn Khir Im I I Grek 1973;110:93.

83. Kerr AA. Cysts and pseudocysts of the pancreas. Surg Gynecol Obstet 1918;27:40.

84. Dennis WA. Dermoid cyst of the pancreas. Surg Clin North Am 1923;3:1319.

85. Decourcy JL. Dermoid cyst of the pancreas. Ann Surg 1943; 118:394.

86. Adsay NV, Hasteh F, Cheng JD, Klimstra DS. Squamouslined cysts of the pancreas: lymphoepithelial cysts, dermoid cysts (teratomas) and accessory-splenic epidermoid cysts. Semin Diagn Pathol 2000;17:56-66.

87. Furukawa H, Kosuge T, Kanai Y, Mukai K. Epidermoid cyst in an intrapancreatic accessory spleen: CT and pathologic findings. AJR Am J Roentgenol 1998;171:271.

88. Kanemaki N, Nakazawa S, Yoshino J, Yamao K, Inui K, Yamachika $\mathrm{H}$, et al. A case of intrapancreatic accessory spleen with epidermoid cyst. Nippon Shokakibyo Gakkai Zasshi 1995;92:1212-6.

89. Morohoshi T, Hamamoto T, Kunimura T, Yoshida E, Kanda $\mathrm{M}$, Funo K, et al. Epidermoid cyst derived from an accessory spleen in the pancreas. A case report with literature survey. Acta Pathol Jpn 1991;41:916-21.

90. Nakae Y, Hayakawa T, Kondo T, Shibata T, Kitagawa M, Sakai $\mathrm{Y}$, et al. Epidermoid cyst occurring in a pancreatic accessory spleen. J Clin Gastroenterol 1991;13:362-4.

91. Tang X, Tanaka Y, Tsutsumi Y. Epithelial inclusion cysts in an intrapancreatic accessory spleen. Pathol Int 1994;44:652-4.

92. Davidson ED, Campbell WG, Hersh T. Epidermoid splenic cyst occurring in an intrapancreatic accessory spleen. Dig Dis Sci 1980;25:964-7.

93. Yamada K, Murao S, Yoshida H, Nakajima T, Yoshii M, Kimura M, et al. A case of accessory splenic epidermoid cyst [Japanese]. Nippon Naika Gakkai Zasshi 1981;70:1007-11.

94. Jibu T, Nagai H, Senba D. A case of epidermoid cyst occurring in an intrapancreatic accessory spleen [Japanese]. Jpn J Gastroenterol 1987;84:1859-62.

95. Paal E, Thompson LD, Heffess CS. A clinicopathologic and immunohistochemical study of ten pancreatic lymphangiomas and a review of the literature. Cancer 1998;82:2150-8.

96. Arai T, Kino I, Nakamura S, Ogawa H. Epidermal inclusions in abdominal lymph nodes. Report of two cases studied immunohistochemically. Acta Pathol Jpn 1992;42:126-9.

97. Carr RF, Tang CK, Carrozza MJ, Rodriguez FC. Unusual cystic epithelial choristoma in a celiac lymph node. Hum Pathol 1987;18:866-9.

98. Horie Y, Taguchi K, Akagi T, Ohta T. Lymphoepithelial cyst in peripancreatic lymph node. J Okayama Surg Pathol Assoc 1990;27:53-7.

\section{Book Review}

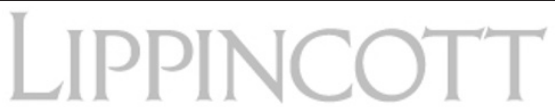

\section{Damjanov I: Pathology Secrets, 525 pp, Philadel-} phia, Hanley \& Belfus, Inc., 2002 (\$37.95).

This text is for medical students use as a succinct complement to the standard pathology sources, for seminar and discussion group preparation, and as a review for USMLE pathology questions. Occasional mnemonics and some 2000 questions are included to aid the study process.

The book is thoughtfully organized and sequenced into the classical subjects seen in standard pathology texts. Five authors contribute five of the 24 chapters, while the author does the remainder. Each chapter is subdivided by questions that are a mixture of lower and upper taxonomic types. The subject areas constitute a relatively comprehensive treatment of pathology core knowledge for a volume of this size. Particularly notable for their excellence are the digestive system chapters: gastrointestinal tract, hepatobiliary, and pancreas. The molecular basis of neoplasia is likewise well done. The chapters on nutritional disease and infectious disease are a bit spare.

Simple but instructive black and white drawings are included in each chapter. Those submitted by the author are particularly instructive. These drawings are employed especially well in the gastrointestinal, pancreatic, renal, and male genital chapters. The author skillfully uses tables; even more could have been utilized throughout the text. A greater effort to include brief clinical descriptions would have been helpful.

Pathology Secrets is best used as a guide after having read the subject area in a standard text. The subject areas are presented in a way that will spark an "aha!" of understanding by many students. Medical students should strongly consider using this text as a study guide during their pathology instruction.
James R. Newland
University of Nebraska Medical Center
Omaha, Nebraska 